\title{
Doğu Akdeniz'deki Doğal Gaz Rezervlerinin Ekonomik ve Güvenlik Boyutuyla Türkiye Açısından Değerlendirmesi
}

\author{
Assessment of Natural Gas Reserves \\ in East Mediterranean with Economy \\ and Security Dimension in Terms of Turkey
}

\author{
Hüseyin Tamer HAVA*
}

\begin{abstract}
$\ddot{O} z$
Doğu Akdeniz, geçmişten günümüze kadar olan her dönemde jeopolitik, jeoekonomik ve jeostratejik öneme sahip olmuştur. Ulaşım, ticaret gibi konularda merkez bölge olma konumunu hiç kaybetmemiştir. Son zamanlarda bölgede bulunan önemli miktardaki hidrokarbon rezervlerinin bölgenin enerji merkezi olma potansiyelini artırmast ve tüm tarafların uzlaştı̆̆ münhasır ekonomik bölgelerinin bulunmayışı buraya yönelik kiyasıya yaşanan mücadelenin giderek artacağını göstermektedir. Coğrafi konum olarak küresel enerji hareketliliğine sahne olan Türkiye'de bu mücadelenin bir parçasıdır. Bu doğrultuda elbette ki Türkiye'de bölgesel enerji merkezi olmayı hedeflemektedir. Ancak bu çeşitli riskleri de beraberinde getirmektedir. Bu perspektiften hareketle çalışmada, bölgede son zamanlarda yaşanan gelişmelerin yarattı̆̆ sonuçlar, jeopolitik, jeostratejik, jeoekonomik ve uluslararast güvenlik boyutlartyla incelenerek çözüm önerilerinde bulunulacaktır.
\end{abstract}

Anahtar Kelimeler: Doğu Akdeniz, Enerji Kaynaklart, Uluslararası Ekonomi, Politik Ekonomi, Güvenlik.

\footnotetext{
* Dr. Öğr. Üyesi, Millî Savunma Üniversitesi, Hava Astsubay Meslek Yüksek Okulu, ORCID: 0000-0002-5104-6688, e-posta: thava@msu.edu.tr, tamerhava@ gmail.com. 
676

Güvenlik Stratejileri

Cilt: 16

Sayı: 35

\section{Abstract}

Eastern Mediterranean has had geopolitical, geoeconomic and geostrategic significance in every period from past to present. It has never lost its feature of being central in issues such as transportation and trade. Lately, the fact that the significant amount of hydrocarbon reserves increased the potential of the region to become an energy hub and the absence of exclusive economic zones with which all parties have agreed show that the fierce competition for this region will gradually increase. Situated in the global energy mobility as geographical location, Turkey is also a part of this competition. In line with this, of course, Turkey also aims to become a regional energy hub. However, this aim brings with it various risks. Based on this perspective, the results of recent developments in the region will be analyzed with geopolitical, geostrategic, geoeconomic and international security dimensions and solutions will be proposed.

Keywords: Eastern Mediterranean, Energy Resources, International Economy, Political Economy, Security.

\section{Giriş}

Ülkelerin toplumsal gelişimlerinin sürükleyici unsurlarının başında enerji kullanımı gelmektedir. Enerji kaynakları ve enerji sanayi üretiminin, sanayi ürünleri ise günlük yaşamımızın en önemli ve yaşamsal girdileridir. Bu nedenle de ülkenin ve enerji alanının yönetimlerini üstlenenler, toplumun ve ekonominin gereksinim duyduğu enerjiyi kesintisiz, güvenilir, zamanında, temiz ve ucuz yollardan temin etmek, enerji arz güvenliği açısından bu kaynakları çeşitlendirmek zorundadır. ${ }^{1}$

Bölgeye modern hayatın en temel ve vazgeçilemez parçalarından birini oluşturan enerji açısından bakıldığında ise, burada bulunan enerji kaynakları söz konusu ülkeler açısından daha kritik hale gelmektedir. $\mathrm{Bu}$ bağlamda, gelişen teknolojiyle birlikte tüketimin hızlanarak

1 Necdet Pamir, "Enerji Politikaları ve Küresel Gelişmeler”, 57-73, s. 57, https://docplayer.biz.tr/31939987-Enerji-politikalari-ve-kuresel-gelismeler.html (Erişim Tarihi: 13.07.2020). 
ihtiyaçların artması sonucunda mevcut enerji kaynaklarının yetersiz kalması, devletleri zamanla yeni enerji kaynaklarının keşfedilmesine yöneltmiş ve deniz kaynaklarından yararlanma arzusunu ortaya çıkarmıştır. Bu çerçevede 20. yüzyıla kadar süregelen denizlerdeki kara suları ve açık deniz uygulamalarına, 20. yüzyılın sonlarına doğru iç sular, bitişik bölge, kıta sahanlığı ve münhasır ekonomik bölge kavramları da ilave olmuştur. ${ }^{2} 21$. yüzyılın başlarında yoğunluk kazanan denizlerdeki yeni enerji kaynaklarının keşfi konusu, bu kaynaklara hâkim olabilmek adına ülkelerin o bölgede hâkimiyetini artırma çalışmalarına ve hatta bunun daha ötesinde ülkeler arasında çatışmalara dönüşmesine neden olmaktadır. Buna konu olan bölgelerin başında Doğu Akdeniz gelmektedir.

Doğu Akdeniz tarih boyunca köklü tarihi ve kültürü, ticaret merkezi misyonu ile her dönemde jeopolitik, jeostratejik ve jeoekonomik açıdan kritik öneme sahip olan bir bölge olarak karşımıza çıkmaktadır. $\mathrm{Bu}$ açılardan bakıldığında küresel hegemon ve bölgesel güçler kendi çıkarlarını korumak için bölgeye karşı sürekli duyarlı olmuştur. Bölgenin stratejik açıdan önemli noktası adeta gözetleme kulesi gibi olan Kıbrıs adasıdır. Kıbrıs adası geçmişten beri kritik önem arz ettiği gibi, günümüzde bölgede yaşanan mevcut gelişmelerde de başat rolünü korumaktadır. Türkiye için ise, Doğu Akdeniz ve Kıbrıs meselesi hem ulusal çıkar hem de ulusal güvenlik meselesi olmuştur. Ancak hemen hemen bölgeye yönelik kararlı ve titiz politika söz konusu olmamıştır. Fransa başta olmak üzere Avrupa Birliği (AB), bölgede aktif olma niyetini adada siyasi çözüm bulunmadan Güney Kıbrıs Rum Yönetimi'ni (GKRY) Birliğe üye kabul ederek göstermiştir. Aksu'ya ${ }^{3}$ göre $\mathrm{AB}$ daha da ileriye götürerek Yunanistan ve GKRY'nin üyeliğe kabulünden sonra bu ülkelerin taraf olduğu deniz yetki alanlarına ilişkin sorunları içselleştirmiş, Ege Denizi ve Kıbrıs’tan oluşan bölgeyi

\footnotetext{
${ }^{2}$ Hüseyin Pazarcı, Uluslararası Hukuk, Turhan Kitabevi, Ankara, 2008, s. 251-252.

${ }^{3}$ Fuat Aksu, "Doğu Akdeniz Deniz Yetki Alanları Sorunu ve Türkiye-AB İlişkileri", Sertaç Hami Başeren, (Yay. Haz.), Doğu Akdeniz'de Hukuk ve Siyaset, A.Ü. Siyasal Bilgiler Fakültesi Yayınları, Ankara, 2013, 159-196, s. 162.
}

\section{7}

Güvenlik Stratejileri

Cilt: 16

Say1: 35 
678

Güvenlik Stratejileri

Cilt: 16

Sayı: 35
Birliğin sınırları içinde görmüşlerdir. Amerika Birleşik Devletleri (ABD), Rusya Federasyonu (RF) ve İngiltere'nin bölgedeki varllğ 1 ise son derece hissedilir boyutlardadır. İsrail de Akdeniz'e kıyısı olan bir devlet olması nedeni ile Doğu Akdeniz'de uygulanacak politikalarda etkin rol oynamaktadır. Yunanistan ve GKRY'nin stratejik ortak olarak hareket etmeleri ve politika oluşturmaları da denklemin farklı bir boyutunu oluşturmaktadır.

Enerji kaynaklarına sahip olmanın ülkelere sağladığı avantaj, kullanımı en yaygın olan ve doğada diğer kaynaklara göre görece daha az bulunan petrol ve doğal gaza sahip olunması ile ciddi oranda artmaktadır. Bu çerçevede, Doğu Akdeniz bölgesinde 2000'li yılların başından bugüne kadar stratejik öneme sahip hidrokarbon yeraltı zenginlik rezervlerinin keşfi ve muhtemel beklenen keşifler, bölgeyi ön plana çıkarmış, buna bağlı olarak yetki alanlarının, arama-üretim ruhsat sahalarının belirlenmesi gibi konularda sorunları da beraberinde getirmiştir. Doğu Akdeniz bölgesinde tüm bu faaliyetler nedeniyle hareketlilik yaşanmakta ve uzlaşabilen ülkeler arasında anlaşmalar yapılmaktadır. Bölgede tek taraflı veya ikili anlaşmalarla ilan edilen Münhasır Ekonomik Bölgeler'in (MEB), ülkeler arasında tam bir mutabakat oluşmadan verilen ruhsatların ve bazı parsellerde çakışmaların olması gibi sebeplerin yeni krizleri doğuracağı açıkça görülmektedir. Siyaset, ekonomi ve güvenlik kavramlarının hepsinin etkin olduğu bu bölgede üretim faaliyetleri yürütmek ve devamlılık sağlamak için geniş bir mutabakat anlaşmasının gerçekleşmesi pek muhtemel gözükmemektedir.

Bölge devletleri, keşfedilen yeraltı enerji kaynakları ve bunların ekonomide değerlendirmesi hususunu yürüttükleri dış politika esasları çerçevesinde belirlemektedirler. Bunun, aynı zamanda bölgede geniş güvenlik kaygılarının var olmasından kaynaklandığı da söylenebilir.

$\mathrm{Bu}$ çalışmada bölgede son zamanlarda yaşanan gelişmelerin yarattığı sonuçların jeopolitik, jeostratejik, jeoekonomik ve uluslararası güvenlik boyutlarıyla incelenmesi amaçlanmış ve çözüm önerileriyle literatüre katkı sağlayacağ düşünülmüştür. Çalışma araştırma makalesi niteliğinde olduğundan, verilerin elde edilmesi belge tarama yöntemi ile gerçekleştirilmiştir. 
Çalışmanın ilk bölümünde, Doğu Akdeniz'in jeopolitik, jeoekonomik, jeostratejik önemi ve Kıbrıs konusu ele alınmış, ikinci bölümünde ise; Doğu Akdeniz'de bulunan doğal gaz rezervlerinin büyüklükleri ve ekonomik değerleri, enerji pazarlarına ulaşım konularına değinilmiş ve Türkiye açısından durum değerlendirilmiştir. Daha sonra da Doğu Akdeniz'de bulunan doğal gaz rezervlerinin politik ekonomisi ve uluslararası alanda güvenlik boyutlarına etkisi tartışılmış ve çalışma elde edilen bulguların analizi ile sonuçlandırılmıştır.

\section{Doğu Akdeniz'in Jeopolitik, Jeoekonomik, Jeostratejik Önemi ve Kıbrıs}

Akdeniz, Dünya üzerinde bulunduğu yer itibari ile hem eski medeniyetlerin yaşadığı coğrafyaya yakın hem de kıtaların kesiştiği bir noktada bulunmaktadır. Akdeniz kelimesinin İngilizce karşılığ olan Mediterranean tanımlamasının sözlükteki karşılığı "Dünya'nın Ortası" anlamına gelmektedir. ${ }^{4}$ Akdeniz genel olarak bakıldığında Avrupa ve Afrika kıtaları arasında bulunmasına rağmen, Akdeniz'in doğusu olarak tanımladığımız Doğu Akdeniz; Avrupa, Afrika ve Asya kıtalarının kesiştiği önemli bir kavşak noktası olarak karşımıza çıkmaktadır. Doğu Akdeniz, jeopolitik teoriler olan Kara Egemenliği Teorisi, Kenar Kuşak Teorisi, Deniz Hâkimiyet Teorisi ve Hava Hâkimiyet Teorisi ile önemi tescillenmiş bir bölgedir. Doğu Akdeniz'in en kritik ve önemli adası ise bölgenin merkezinde bulunan Kıbrıs adasıdır. ${ }^{5}$ Bu kapsamda tüm bu teorilerin Kıbrıs'ın jeopolitiğini açıklamakta yeterli olup olmadığı açıklığa kavuşmamıştır. Ancak Kıbrıs'ın coğrafyasının kara, hava ve deniz unsurlarıyla birlikte bir bütün olarak ele alınması gerektiği de açıktır. ${ }^{6}$ Diğer taraftan, dünyaya egemen olabilme çabalarını değişik

\footnotetext{
${ }^{4}$ Levent Ağaoğlu, Kıbrıs Dünyanın Merkezidir, Hiperlink Yayınları, İstanbul, 2018, s. 24.

${ }^{5}$ Dursun Yıldız, Doğu Akdeniz'de Isınan Sular, Bizim Kitaplar Yayınları, İstanbul, 2009, s. 13-23.

${ }^{6}$ Soyalp Tamçelik, "Jeopolitik Teoriler Açısından Kıbrıs'ın Önemi (The Importance Of Cyprus Island in Geopolitical Theories)", Center for Turkish Studies Occasional Paper Series-Book 3, 2011, 1-32, s. 10 http://pdxscholar.library.pdx.edu/turkish studies_occasionalpaper/3 (Erişim Tarihi: 09.07.2020).
}

\section{9}

Güvenlik Stratejileri

Cilt: 16

Say1: 35 
680

Güvenlik Stratejileri

Cilt: 16

Sayı: 35

bakış açılarıyla ele alan bu teoriler, bir anlamda küresel jeopolitiğe de yön vermiştir. Bununla beraber tarihsel süreç içinde başta bölgeye yakın uygarlıklar olmak üzere birçok uygarlık, dünya ticaretini kontrol edebilmek için bölgeye yönelik olarak kara ve deniz yollarını hâkimiyetleri altına almaya çalışmışlardır. ${ }^{7} \mathrm{Bu}$ çerçevede dikkatler küresel ekonomik jeopolitiğe çevrilmiş, enerji kaynaklarının ve bunların ulaştırma hatlarının kontrol edilerek küresel ekonomik egemenlik sağlanmaya çalışılmıştır. Bu ise hangi coğrafi bölge/bölgelerin kontrol edilmesinin gerektiği sonucunu ortaya çıkarmıştır. Bu sorunun cevabı Avrupa ve Asya kıtaları olarak genel kabul görmektedir. Kendi içinde ise Doğu Akdeniz'de yoğunlaşmaktadır. Bunun paralelinde Doğru'nun da belirttiği gibi, ${ }^{8}$ bölgede keşfedilen hidrokarbon yatakları ve bu nedenle Kıbrıs konusunda yaşanan uyuşmazlıklar, dünyadaki önemli deniz ulaştırma yollarının Doğu Akdeniz'den geçmesi ve yaşanan diğer önemli gelişmeler nedeniyle bölgenin tarihsel süreçte taşıdığ önem günümüze gelindiğinde daha çok artmıştır. Bununla beraber, bölgede uzun yıllar boyunca çözülemeyen sorunlara doğal gaz kaynaklarının çıkarılması ve paylaşılması sorunu olarak bir yenisi daha eklenmiştir. $\mathrm{Bu}$ sorun bölgedeki mevcut sorunları daha da derinleştirme riskini taşımakla birlikte, aynı zamanda da çözümüne katkı sağlayabilecektir.

Dünya ticaretinin \%80'den fazla bir bölümü deniz yolları ile yapılmaktadır. Doğu Akdeniz'in deniz yollarının kritik geçiş ve kavşak noktalarından birisinde yer alması önemini daha da artırmaktadır. Akdeniz bu özelliği sebebiyle tarihin her döneminde uluslararası ticaret ve uluslararası siyaset alanlarında güç mücadelelerine sahne olmuştur. 18. yüzyılda Osmanlı Devleti, savaşlar zamanında Akdeniz'de ticareti

${ }^{7}$ Cihat Yaycı, "Doğu Akdeniz'de Deniz Yetki Alanlarının Paylaşılması Sorunu ve Türkiye”, Bilge Strateji, 2012, 4(6), 1-70, s. 3 https://dergipark.org.tr/en/pub/bs/ issue/3804/51021 (Erişim Tarihi: 25.12.2019).

${ }^{8}$ Sami Doğru, "Doğu Akdeniz'de Hidrokarbon Kaynakları ve Uluslararası Hukuka Göre Bölgedeki Kıta Sahanlığı ve Münhasır Ekonomik Bölge Alanlarının Sinırlandırılması", Türkiye Barolar Birliği Dergisi, 2015, Sayı 119, 503-554, s. 506 https://hdl.handle.net/20.500.12507/96 (Erişim Tarihi: 08.07.2020). 
sekteye uğratan korsan faaliyetleri durdurmak ve denizlerde hâkimiyeti sağlamak amacıyla güvenlik tedbirleri almıştır. Mora Yarımadası'nın Venedik'ten geri alınmast ile denizlerde emniyet tesis edilmesi sağlanmıştır. ${ }^{9}$

Denizlerde hâkimiyet sağlamak için hem sivil hem de askerî denizciliğe önem verilmesi, bu kapsamda güçlü bir donanmaya sahip olunması önemlidir. 19. yüzyılda Doğu Akdeniz'de güç mücadelesinde öne çıkan ülkeler; Osmanlı Devleti, İngiltere, Rusya ve Fransa olmuştur. $\mathrm{Bu}$ dönemde yaşanan savaşlarda donanmalar önemli roller üstlenmiştir. Eski, köklü ve büyük medeniyetlere ev sahipliği yapan Akdeniz, uluslararası ticaretin ve güç mücadelelerinin merkezinde oluşan derin kültürü ile de tüm dünyayı etkilemiştir. ${ }^{10}$

Akdeniz uluslararası ticaretin tarihsel gelişimi açısından da önemli bir yer tutmaktadır. İpek yolu ticaretinde batıya uzanan hat üzerinde bulunan Doğu Akdeniz, her dönemde savaşlardan daha çok ticaretle ön plana çıkmıştır. Kıbrıs'ı veya Doğu Akdeniz'i çevreleyen diğer topraklarda egemenlikler değişse dahi, ticaret hızla canlanarak devamlılık göstermiştir. Akdeniz uygarlığını geliştiren sadece ticaret, konum, iklim gibi özellikleri olmamış, aynı zamanda birçok semavi dinin doğduğu, etkileşimde bulunduğu ve birlikte yaşadığı bir bölge olması da buna katkıda bulunan en büyük değerlerden birisi olmuştur. Keza, uluslararası alanda yaşanan siyasal güç mücadelelerinde avantajlı konuma geçmenin yollarından biri de ulaşım, ticaret ve taşıma yollarını elinde bulundurmaktır. Doğu Akdeniz, Orta Doğu ve Hazar coğrafyasında bulunan petrol ve doğal gaz gibi enerji kaynaklarının taşınması ve dünya pazarına ulaştırılması kritik bir öneme sahiptir. Süveyş Kanalı ve Güneydoğu Asya ekonomisinin ticaret kabiliyetlerinin gelişmesi de aynı şekilde Doğu Akdeniz'in ticari önemini artırmaktadır.

\footnotetext{
${ }^{9}$ Yusuf Alperen Aydın, “18. Yüzyılda Osmanlı Devleti’nin Ege (Adalar) Denizi ve Doğu Akdeniz'e Yönelik Güvenlik Parametreleri”, Osmanl Araştırmalarl / The Journal of Ottoman Studies, 2015, Say1 45, 161-184, s. 161-163.

${ }^{10}$ Fatih Erbaş, "19. Yüzy1l Doğu Akdeniz Donanma Mücadelesinde Öne Ç1kan Devletler ve Faktörler", FSM İlmî Araştırmalar İnsan ve Toplum Bilimleri Dergisi, 2016, Say1 8, 133-158, s. 134.
}

\section{1}

Güvenlik Stratejileri

Cilt: 16

Say1: 35 
682

Güvenlik Stratejileri

Cilt: 16

Sayı: 35

Doğu Akdeniz'de kontrol kulesi gibi görev yapan, Anadolu'daki Toros Sıra Dağları'nın devamının denizde yükselmiş bölümü olan Kıbrıs Adası, Doğu Akdeniz'in, dolaylı olarak Anadolu'nun ikmal yollarının anahtarını elinde bulundurmaktadır. Dünya genelinde ve gelişmekte olan ülkelerin enerji talebinin artmasi enerji merkezlerine olan ilgiyi arttırmıştır. Ayrıca küresel terör faaliyetlerinin kaynağı ve yönetim merkezi olan topraklara küresel veya bölgesel güçlerin operasyonel anlamda da ilgileri artmıştır. Tüm bu çarpanlar düşünüldüğünde Doğu Akdeniz, kıyıları ve Kıbrıs önemli bir jeopolitik, jeoekonomik ve jeostratejik gücü elinde bulundurmaktadır. ${ }^{11} \mathrm{Bu}$ vazgeçilmez özellikleriyle bölge, geçmişte olduğu gibi günümüzde de sadece bölgesel güçlerin değil, küresel güçlerin de ilgisini çekmektedir.

Bölgede hem askerî hem de ticari manada Kıbrıs adası kilit rol oynamaktadır. Kıbrıs, Türkiye için güney sahillerinin emniyetini sağlamak, herhangi bir seferberlik veya savaş durumunda ikmal hatlarının açık kalması bakımından çok büyük önem arz etmektedir. Türkiye açısından, Kıbrıs'ın düşman bir kuvvetin elinde bulunma senaryosunda güney sahillerine büyük miktarda kuvvet yerleştirmesi zorunluluğu öngörülmektedir. Türkiye için ileri üs konumunda olan Kıbris, ayrıca Orta Doğu'da bulunan Akdeniz devletlerine ekonomik, askerî ve politik baskı yapabilme olanağı da sunmaktadır. Gazi Mustafa Kemal Atatürk, savaşta ikmalin önemine dikkat çekerek Kıbrıs'ın ikmal yollarının tıkanmaması için mutlaka çaba sarf edilmesi ve önlem alınması gerektiğini vurgulamıştır. Küresel bir güç olan $A B D$, Kıbrıs ve bölge açısından birinci dereceden kaygılar taşımamakla birlikte, diğer güçlere karşı çıkarlarını korumak için bölgede etkinliğini ve varlığını göstermektedir. ABD'nin bölgede ticaretten daha çok güvenlik kaygıları yönüyle politika geliştirdiği görülmektedir. ABD'nin Doğu Akdeniz politikası daha çok Türk-Yunan ilişkileri, İsrail'in güvenliği ve Orta Doğu'nun istikrarı çerçevesinde ş̧ekillenmektedir. Diğer taraftan başta Fransa olmak üzere AB, bölgede ve Kıbrıs'ta nüfuz alanını

${ }^{11}$ Dursun Yıldız, Akdeniz'in Doğusu (Tarihi Geçmişi, Stratejik Önemi ve Su Sorunu Açısından), Bizim Kitaplar Yayınevi, İstanbul, 2008, s. 91-100. 
artırmak istemektedir. Bunun nedenlerini ekonomik, stratejik ve prestij başlıkları ile açıklamak mümkündür. Avrupa, bölgenin ve Kıbrıs adasının artan jeopolitik, jeoekonomik ve jeostratejik öneminden kaynaklı çıkarlarını korumak, hatta coğrafi yakınlıktan ötürü etkinliğini artırarak gerek güvenlik ve enerji gerekse Asya ve bölge çevresi ile ticarette daha ileri noktalara ulaşmak için girişimlerde bulunmaktadır. Bu bağlamda, Kıbrıs sorunu çözülmeden Kıbrıs Rum Yönetimi’nin Avrupa Birliği'ne alınması, diğer devletlerin üyeliğe alınma süreçleri ile karşılaştırıldığında görece hızlı bir şekilde gerçekleşmesi Avrupa Birliği'nin Kıbrıs meselesine bakış açısını açıkça ortaya koymaktadır. Ayrıca, Avrupa'nın askerî etkinliğini de dolaylı olarak artırmasının beklenen bir sonuç olarak karşımıza çıkacağı da düşüncelerden uzak tutulmamalıdır. Kıbrıs adası üzerinde resmen toprak sahibi olarak askerî üs bulunduran, $\mathrm{AB}$ üyeliğinden ayrılmak üzere olan ve ABD'nin stratejik ittifakı İngiltere, adada sorunun çözümüne dair inisiyatif ve söz sahibi olması sebebi ile konuya daha hassas ve etkin katılım göstermektedir. İngiltere adada etkinliğini sürdürerek bölgesel çıkarlarını ve eski Büyük Britanya İmparatorluğu'ndan gelen bölgedeki etkin statüsünü korumak istemektedir. Rusya Federasyonu ise, dış politikasının önemli temellerinden birini oluşturan sıcak denizlere inmek ve hâkimiyet kurmak hedefini gerçekleştirmek, eski SSCB döneminde olduğu gibi küresel konularda inisiyatif ve karar alabilen bir devlet olduğunu gösterebilmek için bölgede aktif olan güçlerden biri olarak karşımıza çıkmaktadır. Rusya'nın bölgeye yaklaşımı karşılıklı çıkar ve bölgede etkin güç olmak üzerine kuruludur. Rusya, adanın BM kanalı ile silahsızlandırılmasını desteklerken NATO müdahalesine kesin şekilde karşı çıkmaktadır. ${ }^{12}$ Bununla beraber bölgede mevcut olan çıkar çatışmaları, son yıllarda bulunan doğal gaz rezervlerinin kapasitelerin iştah kabartması nedeniyle daha çok ekonomik eksende cereyan etmektedir.

\footnotetext{
${ }^{12}$ Ali Kocamanoğlu, Türkiye Açısından Doğu Akdeniz'in Stratejik Önemi, Deniz Basımevi, İstanbul, 2005, s. 231-240.
}

\section{3}

Güvenlik Stratejileri

Cilt: 16

Say1: 35 
684

Güvenlik Stratejileri

Cilt: 16

Say1: 35

\section{Doğu Akdeniz'de Bulunan Doğal Gaz Rezervleri, Enerji Pazarlarına Ulaşım ve Türkiye}

Doğu Akdeniz'de bulunan doğal gaz rezervleri, bunların dünya pazarlarına ulaştırılması ve Türkiye açısından değerlendirmesinden önce Doğu Akdeniz olarak tanımlanan bölgenin sınırlarını ortaya koymak konunun daha kolay anlaşılabilmesi için önem taşımaktadır. $\mathrm{Bu}$ konuda farkl1 kaynaklarda farklı görüşler bulunmaktadır. Başeren ve Yıldız'a ${ }^{13}$ göre, Tunus'un Bon Burnu'ndan İtalya'nın Sicilya adası batısında kalan Lilibeo Burnu'na çizilen hattın doğusundaki bölge Doğu Akdeniz olarak kabul edilmiştir. Doğu Akdeniz olarak tanımlanan bu bölgenin İtalya'dan başlayarak Kıbrıs'a (Kuzey Kıbrıs Türk Cumhuriyeti-KKTC ve GKRY) kadar uzanan şeritteki ülkelerden (Slovenya, Hırvatistan, Bosna-Hersek, Karadağ, Arnavutluk, Yunanistan, Türkiye, Suriye, Lübnan, Ürdün, İsrail, Filistin, Mısır, Libya, Tunus) oluştuğu söylenebilir. ${ }^{14}$

Akdeniz tarih boyunca jeopolitik, jeostratejik, jeoekonomik ve siyasi önemi açısından daima dikkat çeken bir coğrafi bölge olmuştur. Asya, Avrupa ve Afrika kıtalarını birleştiren Akdeniz, aynı zamanda Karadeniz'e kıyısı olan devletlerin de açık denizlere ulaşabilmesi için tek suyolu olması nedeniyle uluslararası ticarette önemli bir kavşak durumundadır. $\mathrm{Bu}$ özellikleri nedeniyle dünyanın en önemli ticaret güzergâhlarından birisi olan Akdeniz'e hâkim olabilmek için büyük devletler sürekli bir mücadele içinde olmuştur. Özellikle son yıllarda Doğu Akdeniz olarak adlandırılan bölgenin önemi ciddi miktardaki doğal gaz rezerv potansiyeli nedeniyle artmış ve bölgede yer alan devletlerarasında çeşitli sorunlar çıkmasına neden olmuştur. Ancak Orta Doğu Stratejik Araştırmalar Merkezi'nin (ORSAM) yayımladığ 1

${ }^{13}$ Sertaç Hami Başeren, “Doğu Akdeniz Deniz Yetki Alanları Uyuşmazlığı”, Stratejik Araştırma ve Etüt Merkezi Stratejik Araştırmalar Dergisi, 2010, 8(14), 133-135, s. 133; Y1ld1z, “Akdeniz'in..." (2008), a.g.e., s. 4.

${ }^{14}$ Dursun Yıldız ve Doğan Yaşar, Doğu Akdeniz'de Küresel Satranç, Truva Yayınları, İstanbul, 2012, s. 18. 
raporda da ${ }^{15}$ dikkat çekildiği gibi, Birleşmiş Milletler Deniz Hukuku Sözleşmesi'nin (BMDHS) MEB'nin ilanı ile Doğu Akdeniz'e kıyısı bulunan ülkelere egemenlik hakkını mutlak olarak vermediği ve diğer ülkelerin de burada bulunan haklarının saklı tutulduğu belirtilmektedir.

\section{Şekil: 1 İsrail ve GKRY Bölgesinde Önemli Doğal Gaz Rezervi Sahaları ${ }^{16}$}

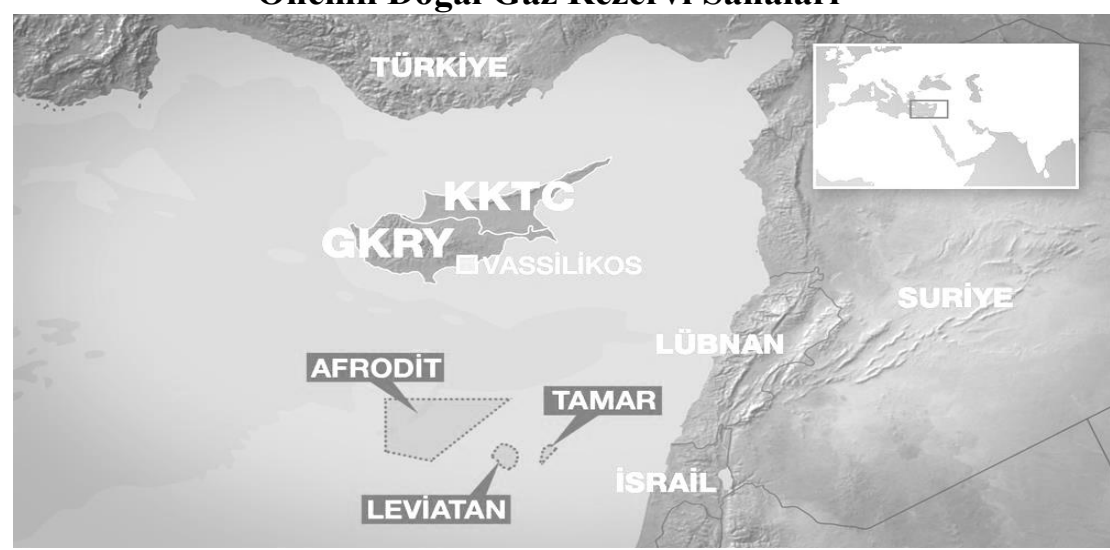

Jessica Robertson tarafindan hazırlanan ve ABD Jeolojik Araştırmalar Merkezi'nin (USGS-United States Geological Survey) yayınladığı raporda; Kıbrıs, Suriye, Lübnan ve İsrail arasında kalan Levant Havzası (Levant Basin) olarak adlandırılan bölgede tahminen 3,45 trilyon metreküp (122 trilyon kübik feetlik) doğal gazın, 1,7

\footnotetext{
${ }^{15}$ Jale Nur Ece, "Kabotaj, Münhasır Ekonomik Bölge, Petrol ve Doğal Gaz Haklarımız", ORSAM (Ortadoğu Stratejik Araştırmalar Merkezi) Raporu, Temmuz 2013, Rapor No: 33, $1-19$, s. 11.

${ }^{16}$ Ömer Lütfi Taşcıoğlu, “GKRY'nin Türkiye Cumhuriyeti'ne ve Kuzey Kıbrıs Türk Cumhuriyeti'ne Ait Deniz Yetki Alanlarındaki Petrol ve Doğal Gaz Arama Çalışmaları ve Münhasır Ekonomik Bölge Anlaşmaları”, Social Sciences Studies Journal, 2018, 4(26), 5697-5709, s. 5698.
}

\section{5}

Güvenlik Stratejileri

Cilt: 16

Say1: 35 
686

Güvenlik Stratejileri

Cilt: 16

Say1: 35

milyar varil petrolün bulunduğuna dikkat çekilmektedir. ${ }^{17}$ Söz konusu bölgeye Misır MEB'sindeki Zohr'un da dâhil olduğunu belirtmekte fayda vardır. ${ }^{18}$ Sadece bu miktardaki rezerv bile Doğu Akdeniz'deki doğal gaz kaynaklarının ne kadar önemli olduğunun bir göstergesidir. Diğer taraftan ABD Jeolojik Araştırmalar Merkezi, Nil Delta Havzası'nda yaklaşık 1,8 milyar varil petrolün, 223 trilyon metreküp doğal gazın ve altı milyar varil sıvı doğal gaz rezervinin olduğunun tahmin edildiğini USGS Fact Sheet 2010-3027 adlı bilgi sayfasında yayınlamıştır. ${ }^{19}$ Bununla beraber, Kıbrıs Adası'nın çevresinde bulunan petrol rezervinin ise sekiz milyar varil, değerinin yaklaşık 400 milyar dolar civarında olduğu açıklanmıştır. ${ }^{20}$ Girit' in güney ve güneydoğusundaki "Herodot" olarak adlandırılan alanda ise toplam 3,5 trilyon metreküplük doğal gaz bulunduğu belirtilmektedir. ${ }^{21}$ Bu bağlamda, Doğu Akdeniz'deki doğal gaz rezervlerinin toplam değerinin üç trilyon doları bulduğu ve günümüzdeki tüketim miktarı baz alındığında, tahminen 572 yıl Türkiye'nin doğal gaz ihtiyacını karşılayabilme potansiyeline sahip olduğu belirtilmektedir. ${ }^{22}$

17 Jessica Robertson, "Natural Gas Potential Assessed in Eastern Mediterranean", USGS Newsroom, 04.08.2010, https://archive.usgs.gov/archive/sites/www.usgs.gov/ newsroom/article.asp-ID=2435.html (Erişim Tarihi: 30.05 .2019 ).

${ }^{18}$ Erdal Tanas Karagöl ve Büşra Zeynep Özdemir, "Türkiye'nin Enerji Ticaret Merkezi Olmasında Doğu Akdeniz'in Rolü”, SETA Raporu, 2017, Yayın No: 92, 1-63, s. 10-13.

${ }^{19}$ USGS, "Undiscovered Oil and Gas of the Nile Delta Basin, Eastern Mediterranean, USGS Fact Sheet 2010-3027, May 2010, https://pubs.usgs.gov/fs/2010/3027/pdf/FS103027.pdf (Erişim Tarihi: 30.05.2019).

${ }^{20}$ Bahadır Selim Dilek, “Akdeniz'de Sanal Petrol Oyunu”, http://www.emo.org.tr/ekler/ c03b704b8bd986e_ek.pdf?dergi=508 (Erişim Tarihi: 30.05.2019).

${ }^{21}$ Muzaffer Ertürk, "Doğu Akdeniz'de Türk-Yunan Enerji Uyuşmazlığı", Journal of Current Researches on Social Sciences, 2017, 7(2), 15-26, s. 16.

${ }^{22}$ Cihat Yayc1, Sorular ve Cevaplar ile Münhasır Ekonomik Bölge (MEB) Kavramı, Deniz Basımevi Müdürlügü, İstanbul, 2019, s. 39. 
Şekil: 2 Doğu Akdeniz'de GKRY ve Kuzey Kıbrıs'ın Parsel Dağılımları ${ }^{23}$

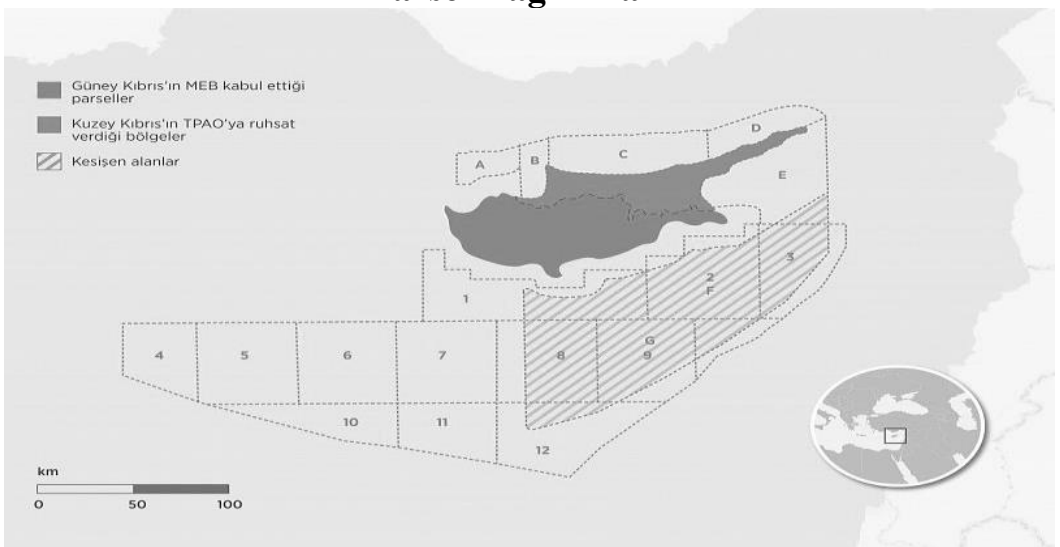

Doğu Akdeniz'deki doğal gaz keşifleriyle ilgili ilk çalışmalar 1980'li yıllarda Mısır kıyılarında yapılmaya başlanmıştır. Son dönemlerde hız kazanan doğal gaz arama çalışmaları sonucunda bölgede yapılan keşiflere ilişkin bilgiler Tablo 1'de verilmiştir. Buradan da anlaşılacağı üzere son y1llarda, özellikle 2009 yılından itibaren Doğu Akdeniz'de enerji kaynaklarını arama çalışmaları yoğunlaşmış oldukça önemli miktarlarda petrol ve doğal gaz yatakları keşfedilmiş, bölgeye kıyısı olan devletlerin önemi artmıştır. Nitekim bölgede ilk büyük doğal gaz keşfi 2009 yılında İsrail MEB'si Tamar sahasında olmuştur. Bunun hemen ardından yine İsrail, Leviathan sahasinda tahminen 509,7 milyar $\mathrm{m}^{3}$ 'lük daha büyük bir rezerv keşfetmiştir. Daha sonra 2015 yılında Mısır, Zohr sahasında 849,0 milyar $\mathrm{m}^{33}$ lük rezervle o zamana kadar olan en büyük keşfi yapmış ve hemen sonraki yıl ise

\footnotetext{
${ }^{23}$ Faruk Can, "Doğu Akdeniz: Ne Kadar Doğal Gaz Rezervi Var, En Büyük Pay1 Hangi Ülkeler Alacak?", EURONEWS, 05.05.2019, https://tr.euronews.com/2019/ 05/05/dogu-akdeniz-ne-kadar-dogal-gaz-rezervi-var-en-buyuk-payi-hangi-ulkeleralacak (Erişim Tarihi: 25.12.2019).
} 
688

Güvenlik Stratejileri

Cilt: 16

Say1: 35

Nur sahasında tahminen Zohr sahasındaki rezerv kadar büyüklükte doğal gaz keşfedilmiştir. GKRY'nin tek taraflı olarak MEB'si kabul ettiği parsellerde sürdürdüğü arama çalışmalarında; 2018 yılında Calypso sahasında, 2019 yılında ise Glaucus-1 sahasında önemli doğal gaz rezervleri keşfedilmiştir. GKRY tarafından Glaucus-1 sahasındaki keşif için, Kıbrıs açıklarında şimdiye kadar bulunan en büyük rezerv olduğu açıklanmıştır.

Doğu Akdeniz'in enerji transferi konusunda sahip olduğu önemine ilaveten son zamanlardaki enerji kaynaklarının keşifleriyle ekonomik potansiyelinin artması ve hâlihazırda Doğu Akdeniz'in birçok yerinde arama çalışmalarının devam etmesi göz önüne alındığında, bölgenin bir enerji merkezi haline gelip ekonomik dengeler açısından öneminin giderek artacağı açıkça ortaya çıkmaktadır. Bu nedenle keşfedilen ve daha sonra keşfedilecek enerji kaynakları üzerinde bölge ülkeleri hak sahibi olabilmek için kıyasıya mücadele etmektedir. Ayrıca bu keşifler, enerji yönünden ağırlıklı olarak Rusya'ya bağımlı olan, yüksek enerji tüketimine sahip Avrupa ülkelerini de yakından ilgilendirmektedir.

Diğer önemli bir konu da bölgedeki enerji kaynaklarının pazara ulaştırılmasıdır. Buna ilişkin üç olası yol öngörülmektedir. Bunlardan ilki, GKRY ile Yunanistan arasında kurulacak bir boru hattıdır. Ancak bu alternatif özellikle mesafe fazlalığı nedeniyle uygulanabilir gözükmemektedir. İkincisi, doğal gazın Arap Gazı Boru Hattı vasıtasıyla İsrail üzerinden taşınmasıdır. Bu alternatif de hem 270 kilometrelik boru hattı ihtiyacı nedeniyle yine mesafe fazlalığı hem de bölgede süregelen çatışmalardan kaynaklanan güvenlik sorunlarından dolayı hayata geçirilmesi pek mümkün görülmemektedir. Üçüncüsü ise, doğal gazın Türkiye üzerinden geçirilecek bir boru hattı aracılı̆̆ıyla taşınmasıdır. Bunun uzunluğu denizde yaklaşı 100 kilometredir. Buradaki uygulamanın Suriye-Ürdün kıyısına paralel ya da KKTC üzerinden olması en uygun olanları olarak öne çıkmaktadır. ${ }^{24}$ Doğu Akdeniz'de

${ }^{24}$ Umut Kedikli ve Deniz Taşkın, "Enerji Kaynakları Mücadelesinde Doğu Akdeniz Havzası ve Deniz Yetki Alanları", Alternatif Politika, Ekim 2015, 7(3), 399-424, s. 413. 
çıkarılacak petrol ve doğal gazın uluslararası pazara ulaştırılmasında söz 689 konusu alternatifler içinde en kısa, akılcı, en ekonomik ve en güvenilir hattın Türkiye üzerinden olacağ 1 açıkça ortadadır. Ancak bu değerlendirmeyle birlikte Türkiye hattının açıkça daha avantajlı olduğu ortada olmasına rağmen, tamamen siyasi nedenlerle İsrail, Yunanistan ve GKRY, 02 Ocak 2020 tarihinde bir başka alternatif proje olarak Doğu Akdeniz Boru Hattı Anlaşması'nı (EastMed Pipeline Agreement) Atina'da imzaladı. Bu projede doğal gazın GKRY-Girit-Mora Yarımadası (Yunanistan)-İtalya güzergâhından geçirilecek boru hattıyla taşınması planlanmakta, maliyetinin 6-15 milyar dolar olacağı tahmin edilmekte; yılda 12 milyar metreküp gaz taşınması öngörülmektedir. ${ }^{25}$ Ayakları yere basmayan ve ekonomik olmayan EastMed Doğal Gaz Boru Hattı Projesi, tamamen Türkiye'yi bertaraf ederek Doğu Akdeniz'deki enerji kaynaklarından hiçbir şekilde pay almamasına yönelik siyasi bir girişim olup, başarılı olma ihtimali uzak görünmektedir.

\section{Tablo: 1 Son Dönemde Doğu Akdeniz'deki Doğal Gaz Keșifleri (1999-2019) ${ }^{26}$}

\begin{tabular}{|c|c|c|c|}
\hline Sahanın Adı & $\begin{array}{c}\text { Tahmini Rezerv } \\
\left(\mathbf{m i l y a r}^{\mathbf{3}} \mathbf{)}\right.\end{array}$ & Sahiplenen Ülke & Keşif Yılı \\
\hline Noa & 1,1 & İsrail-Filistin & 1999 \\
\hline Gazze Marine & 28,3 & Filistin & 2000 \\
\hline Mari-B & 42,5 & İsrail-Filistin & 2000 \\
\hline Dalit & 14,2 & İsrail-Filistin & 2009 \\
\hline Tamar & 283,3 & İsrail-Filistin & 2009 \\
\hline Leviathan & 509,7 & İsrail-Filistin & 2010 \\
\hline
\end{tabular}

\footnotetext{
${ }^{25}$ Sefa Karahasan, “Türkiye'ye Karşı 3'lü Hamle! İmzalar Atıldı”, HÜRRIYET Gazetesi, 02.01.2020, http://www.hurriyet.com.tr/gundem/son-dakika-haberi-turkiyeye -karsi-3luhamle-imzalar-atildi-41411242 (Erişim Tarihi: 03.01.2020).

${ }^{26}$ Merve Aksoy Ercümen, "Doğu Akdeniz Enerji Rekabeti”, İnsani Araştırmalar Merkezi (INSAMER), 09 Eylül 2016, https://insamer.com/tr/dogu-akdeniz-enerjirekabeti_366.html (Erişim Tarihi: 25.12.2019); Can, “Doğu...”, 05.05.2019, a.g.y.
}

Güvenlik Stratejileri

Cilt: 16

Say1: 35 


\section{0}

Güvenlik Stratejileri

Cilt: 16

Sayı: 35

\begin{tabular}{|c|c|c|c|}
\hline Dolfin & 2,3 & İsrail-Filistin & 2011 \\
\hline Afrodit & 198,2 & GKRY & 2011 \\
\hline Şemşon & 8,5 & İsrail-Filistin & 2012 \\
\hline Tanin & 34,0 & İsrail-Filistin & 2012 \\
\hline Kariş & 51,0 & İsrail-Filistin & 2013 \\
\hline Zohr & 849,0 & Misır & 2015 \\
\hline Nur & $-^{*}$ & Misır & 2018 \\
\hline Calypso (6. Blok) & $169,0-226,0$ & GKRY & 2018 \\
\hline Glaucus-1 (10. Blok) & $142,0-227,0$ & GKRY & 2019 \\
\hline
\end{tabular}

* Rezervin tahminen Zohr sahası büyüklüğünde olduğu belirtilmekte olup, fizibilite çalışmaları devam etmektedir.

Diğer taraftan Doğu Akdeniz, taşımacılık ve enerji taşımacıllı̆ı̆ında konum olarak da stratejik öneme sahiptir. Akdeniz, NATO'nun "chokepoint" (tıkanma noktası) adını koyduğu Cebelitarık Boğazı, Sicilya Kanalı, Çanakkale Boğazı, İstanbul Boğazı ve Süveyş Kanalı'ndan oluşan hayati geçiş noktalarını bünyesinde barındırmaktadır. Zira deniz yolu olarak Akdeniz'i kullanan gemilerin sayısı günde yaklaşık 4000'i bulmaktadır. Bunların da yarısından fazlası tankerlerden oluşmaktadır. Diğer bir bakış açısıyla değerlendirildiğinde, bu tüm dünyada günlük gerçekleşen gemi trafiğinin neredeyse yarısı kadardır. ${ }^{27}$ Hazar bölgesi ve Orta Doğu'dan Batı ülkelerine yapılan enerji ihracatı yine buradan yapılmaktadır. Nitekim Süveyş Kanalı, Arap Petrol Boru Hattı (SUMED), Kerkük-Ceyhan Boru Hattı ve 2006 yılında faaliyetine başlayan BaküTiflis-Ceyhan (BTC) Petrol Boru Hattı Suudi Arabistan, Irak ve Azerbaycan petrolünü bu bölge üzerinden uluslararası pazarlara ulaştırmaktadır.

${ }^{27}$ Ulvi Keser ve Gökhan Ak, "Kıbrıs Sorunu ve Deniz Hukuku Bağlamında Doğu Akdeniz'de Yapılması Gerekenler", Kıbrıs Araştırmaları ve İncelemeleri Dergisi, Ocak 2018, 1(2), 95-107, s. 97 https://dergipark.org.tr/tr/pub/kaid/issue/35246/391038 (Erişim Tarihi: 09.07.2020). 


\section{Doğu Akdeniz'de Bulunan Doğal Gaz Rezervlerinin Politik Ekonomisi ve Uluslararası Alanda Güvenlik Boyutlarına Etkisi}

Doğu Akdeniz, günümüzde gelişen jeopolitik ve jeostratejik öneminin yanı sira denizde bulunan yeraltı enerji kaynakları ile jeoekonomik açıdan büyük bir değer içermektedir. Bundan ötürü, bölgede tek taraflı olarak kıta sahanlığı ve MEB alanlarının belirlenmesi konusunda kıyıdaş ülkeler arasında büyük itilaf yaşanmaktadır. 1982 BMDHS ile çeşitli yapıcı düzenlemelere uğrayan MEB tanımlaması ile; en çok 200 mil genişlikte kara ülkesinin doğal uzantısı olan ve deniz yatağı olarak adlandırılan alan, toprak altı ve üstü canlı veya cansız kaynakların kullanımı, işletme ve muhafazası, yönetim hakkı ilgili devlete verilmektedir. ${ }^{28}$ Anlaşılacağı üzere MEB, hak sahibi devlete geniş hak ve yetkiler vermektedir. Bu durum, çıkar çatışmalarının olduğu Doğu Akdeniz'de MEB'in belirlenmesi sorunsalını aynı zamanda siyasal krizlere de dönüştürmektedir. Zira MEB'in belirlenmesinde "ilan" veya "antlaşma" şeklinde yöntemler bulunmaktadır. Bu bağlamda ilan yöntemi uygulamasında, 1982 BMDHS'nin 75'inci maddesine göre MEB ilan etmek için sahildar devlet koordinatları ilan eder ve bir nüshasını BM Genel Sekreterliği'ne gönderir. Ancak antlaşma yönteminde, itilaflı ve birden çok devletin bulunduğu durumlarda BMDHS'nin 74'üncü maddesine göre hakkaniyete uygun bir çözümün bulunması esas teşkil etmek üzere, Uluslararası Adalet Divanı Statüsü'nün 38'inci maddesi doğrultusunda uluslararası hukuka uygun olarak antlaşma yapılması gerekmektedir. Burada hakkaniyete uygun olması; ilgili tarafların varacağı bir uzlaşma, antlaşma esas alınarak çözüme kavuşturulması ve MEB'in tek taraflı ilan edilemeyeceği anlamına gelmektedir. Doğu Akdeniz'de bulunan devletler, ortak bir antlaşma yerine tek taraflı ve ikili antlaşmalar ile MEB ilanı yapmış ve paylaşımlar gerçekleşmiştir. Tek taraflı antlaşmaları yapan GKRY,

\footnotetext{
${ }^{28}$ Nuray Karapınar, "Birleşmiş Milletler Deniz Hukuku Sözleşmesi ve Deniz Alanlarına İlişkin Bazı Kavramlar", MTA Doğal Kaynaklar ve Ekonomi Bülteni, 2015, Sayı 20, 1321, s. 19-20 http://www.mta.gov.tr/v3.0/sayfalar/hizmetler/kutuphane/ekonomi-bultenleri /2015_20/3.pdf (Erişim Tarihi: 27.06.2020).
}

691

Güvenlik Stratejileri

Cilt: 16

Say1: 35 
692

Güvenlik Stratejileri

Cilt: 16

Sayı: 35

Libya, Suriye, Lübnan ve İsrail devletleri itilaf olduğu durumlarda tarafların hakkaniyet çerçevesinde bir uzlaşma ve antlaşma yoluna giderek uluslararası hukuk prensibini uygulamaya koymamışlardır. Bilimsel olarak kanıtlanan çok yüksek değere sahip hidrokarbon zenginliklerini 1990'l1 yıllarda öğrenen GKRY, adada tek egemen yönetim olmamasına rağmen "Kıbrıs Cumhuriyeti" olarak 21 Mart 2003 yilında tek taraflı MEB ilan etmiştir. GKRY, 17 Şubat 2003'de Misır, 17 Ocak 2007'de Lübnan ve 17 Aralık 2010'da İsrail ile ikili antlaşmalar yapmıştır. Burada iki husus dikkati çekmektedir. Birincisi; GKRY'nin adada tek egemen yönetim olmamasına rağmen MEB gibi kritik ve geniş haklar tanıyan önemli bir konuda adanın tamamı adına tek başına karar almasıdır. İkincisi ise; tartışmalı konularda tek taraflı ilan veya ikili antlaşmalar yerine ortak hakkaniyeti gözeten bir antlaşmanın yapılmamasıdır. ${ }^{29} \mathrm{Bu}$ kapsamda Türkiye'nin görüşü, bölgeye kıyıdaş ülkelerin bir araya gelerek hakkaniyet çerçevesi içinde MEB konusunda anlaşmaları yönündedir. Ayrıca Türkiye, GKRY'nin Kıbrıs'ın temsilcisi gibi diğer kıyıdaş ülkelerle yaptığı MEB antlaşmalarını kabul etmemektedir. Bu kapsamda, Lübnan ve Misır hükümetlerine yaptığı baskıyla Lübnan'a antlaşmayı onaylatmamış, Mısır'a da iptal ettirmiştir. ${ }^{30}$ Ancak GKRY'nin uyguladığı bu uluslararası hukuk dışı politika, bölgedeki dengeyi Türkiye aleyhine çevirebilecek potansiyeldedir. Diğer taraftan, Doğu Akdeniz'deki enerji rezervlerinin değerinin trilyonlarca dolar olmas1, soruna bölge dışındaki Fransa gibi devletleri de müdahil etmiştir. ${ }^{31}$

${ }^{29}$ Pınar Akarçay ve Gökhan Ak, "Ulusal Güvenlik Bağlamında Kıbrıs: Jeostratejik/ Jeoekonomik Önem ve Gelişmeler", Çeşm-i Cihan Tarih Kültür ve Sanat Araşttrmaları EDergisi, Yaz 2018, 5(1), 140-157, s. 150, https://dergipark.org.tr/tr/pub/cesmicihan/ issue/38085/427535 (Erişim Tarihi: 09.07.2020); Yayc1, "Doğu..." (2012), a.g.m., s. 13-17.

${ }^{30}$ Soyalp Tamçelik ve Emre Kurt, "Türkiye'nin Münhasır Ekonomik Bölge Algısı ve Yakın Tehdit Alanı: Kıbrı”, Uluslararası Güvenlik Kongresi Bildiriler Kongresi Bildirileri Kitabı, Hasret Çomak ve Ayşegül Gökalp Kutlu, (ed.), Kocaeli Üniversitesi Yayınları, Kocaeli, Nisan 2014, C. 3, 882-913, s. 898, https://www.researchgate.net/publication/ 312057624_Turkiye'nin_Munhasir_Ekonomik_Bolge_Algisi_ve_Yakin_Tehdit_Alani_Kib ris (Erişim Tarihi: 13.07.2020).

31 Soyalp Tamçelik, "Kıbrıs'ın Batı Dünyası Açısından Jeopolitik Önemi ve Siyasî Algilamaları", 2. Uluslararası Kıbrıs Sempozyumu Bildiriler Kitabl-(21-25 Ekim 2010 
GKRY'nin ikili anlaşmaya bile gerek duymadan kendi başına aldığı kararların, Türkiye'nin sahip olması muhtemel MEB parsellerini açıkça tecavüzü anlamına gelen bu durum Şekil 3'deki haritada görülmektedir.

\section{Şekil: 3 Türkiye'nin Olası MEB'i ve GKRY'nin} 1, 4, 5, 6, 7 Numaralı Parsellere Tecavüzünü Gösteren Harita ${ }^{32}$

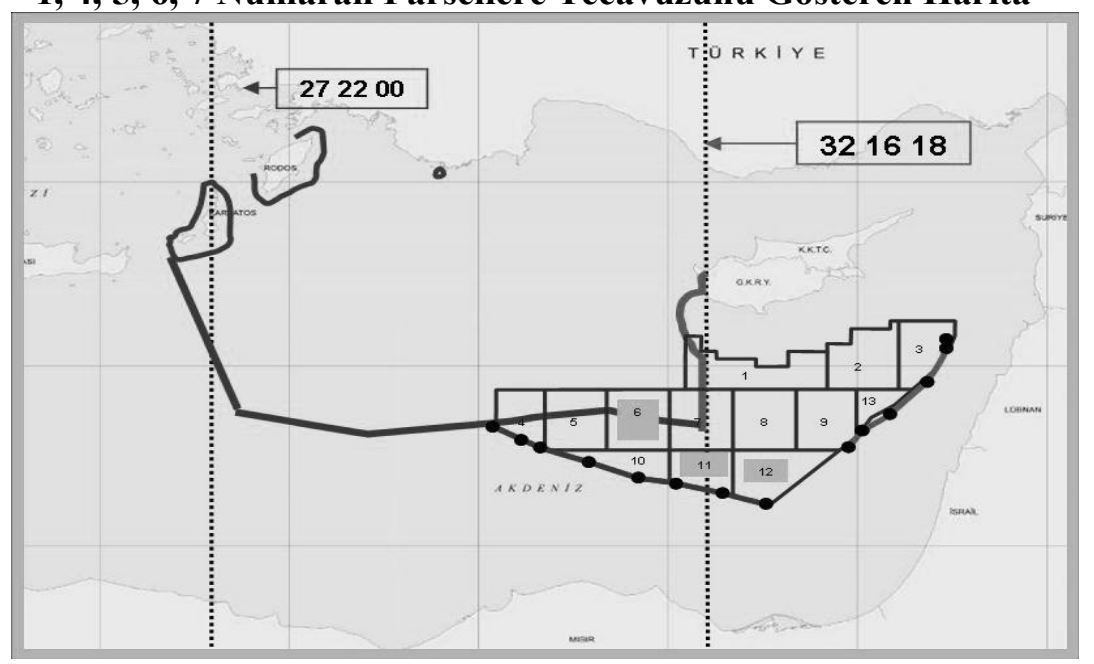

Tarih boyunca güç mücadelelerine sahne olan ve bunun günümüzde de şiddetini arttırarak devam ettiği Doğu Akdeniz Bölgesi, uluslararası arenada kurulan çözüm platformlarının ne kadar sağlıklı çalışacağının test edileceği bir alan haline gelmiştir. Gerek nüfus, gerekse coğrafi ve ekonomik anlamda Doğu Akdeniz'in en önemli güçlerinden biri olan Türkiye, hem kendi hem de Kuzey Kıbrıs Türk Cumhuriyeti'nin

İzmir), Ulvi Keser, (Kıbrıs Türk Kültür Derneği Adına Yay. Haz.), Motif Matbaacılık, Ankara, 2011, C. 3, 225-282, s. 255- 258 https://websitem.gazi.edu.tr/site/soyalp/files (Erişim Tarihi: 13.07.2020).

${ }^{32}$ Yayc1, "Doğu..." (2012), a.g.m., s. 33. 
694

Güvenlik Stratejileri

Cilt: 16

Sayı: 35

uluslararası hukuka dayalı paylaşımından doğan haklarının temsilcisidir. Türkiye Cumhuriyeti ve KKTC münhasır ekonomik bölgelerini açıllayarak, GKRY'nin tek taraflı olarak ilan ettiği toplamda $51.000 \mathrm{~km}^{2}$ olan ve 13 parselden oluşan münhasır ekonomik bölgeye karşı çıkmıştır. Bu kapsamda, Türkiye'nin açıkladığı münhasır ekonomik bölgeye göre; Mısır anakarası ile Türkiye anakarası arasında kalan bölge, kendi haklarından doğan Mısır ve Türkiye arasında paylaşılmalıdır. Dolayısıyla 1., 4., 5., 6. ve 7. parsellerin bir kismının Türkiye'ye ait olmas1 gerekmektedir. Ancak mevcut durumda bu parseller Güney Kıbrıs'ın fiili işgali altındadır. Güney Kıbrıs bu parseller üzerinde hak iddiasına dayalı mevcudiyetini sürdürürken, buradaki arama ve işletme faaliyetlerini; 2., 3. ve 9. parseller için İtalya'nın Eni ve Güney Koreli Kogas şirketlerine, 8. parseli İtalyan'ın Eni grubuna, 6. ve 11. parselleri Fransa'nın Total ve İtalya'nın Eni gruplarına, 10. parseli ABD'nin Exxon Mobil ve Katar Petroleum ortaklığına, 12. parseli ise ABD'nin Nobel, İngiltere'nin BG, İsrail'in Delek ve Avner şirketlerine vermiştir. ${ }^{33}$

Bölgede yaşanan bu gelişmeler, bölge devletleri ve bölge devletleri ile siyasal ilişki içinde olan tüm devletler bakımından önem arz etmektedir. Türkiye ve KKTC de Doğu Akdeniz'deki bu gelişmelere tarafsız kalmayarak, buradaki uluslararası hukuktan kaynaklanan haklarını korumuştur. Bununla beraber Türkiye, Karadeniz, Akdeniz ve Ege Denizi'nde doğal ve herhangi bir ilana bağlı kalmadan, kendiliğinden (ipso facto) ve başlangıçtan beri (ab initio) kıta sahanlı̆̆ı haklarına da sahiptir. Bundan ötürü, Türkiye ile kıta sahanlığına sahip kıyıdaş devletlerin, buralarda gerçekleştirecekleri faaliyetlerden önce Türkiye ile irtibata geçerek iş birliğini sağlamaları gerekmektedir. ${ }^{34}$

33 Gökhan Ak, "Kıbrıs Adası Çevresindeki Deniz Dibi Hidrokarbon Zenginliklerinin Adadaki Sorunun Çözümüne Muhtemel Etkileri”, Motif Akademi Halkbilimi Dergisi, 2013, Sayı 1 (Kıbrıs Özel Sayısı-I), 333-338, s. 335, https://dergipark.org.tr/tr/pub/mahder/issue/ 28390/301912 (Erişim Tarihi: 09.07.2020); Muhsin Barış Tiryakioğlu, "Doğu Akdeniz'de Enerji Denklemi-1", Anadolu Ajansl, 09.05.2019, https://www.aa.com.tr/tr/analiz/doguakdenizde-enerji-denklemi-1/1474137 (Erişim Tarihi: 12.04.2020).

${ }^{34}$ Erdi Şafak, "Doğu Akdeniz'de Enerji Bağlamında Değişen Dengeler", Yakın Doğu 
Doğu Akdeniz'de son yıllarda İsrail'de Leviathan, Tamar ve Misır'da Zohr sahalarında bulunan doğal gaz rezervleri dikkatleri bölgedeki yeraltı enerji kaynaklarına yönlendirdi. Bölgede tüm tarafların razı olduğu nihai bir MEB anlaşması olmadığından, bölge ülkelerinin bu konudaki tutumları farklılık göstermektedir. Ayrıca, bulunan kaynakların ihtiyaç duyulan pazarlara nasıl ulaştırılacağı da ayrı bir sorun olarak karşımıza çıkmaktadır. Bölgedeki devletler ve hükümetler, sergiledikleri politik duruş ve icra ettikleri dış politikaları çerçevesinde, ortaya çıkan bu ekonomik değerlerin kullanımı, paylaşımı ile ilgili kararlar almaktadır. Bununla beraber Türkiye, Doğu Akdeniz'de kurulan bu ittifakların ve anlaşmaların dışında bırakılmak istenmiş veya bırakılmıştır. Ancak, Türkiye çıkarlarını korumak için sismik arama ve sondaj faaliyetlerini kendi ilan ettikleri alanlarda donanmanın eşliğinde yürütmektedir. ${ }^{35}$ Gerçekleştirilen bu faaliyetler, bölge devletlerince kabul görmemiş ve çeşitli boyutlarda krizlere neden olmuş, ancak Türkiye faaliyetlerine devam etmiştir.

Türkiye son dönemde Doğu Akdeniz'deki gelişmeleri birer güvenlik meselesi olarak görmekle birlikte, GKRY'nin tek taraflı arama faaliyetleri yapmasını ve bulunan doğal gaz rezervleri sayesinde yaşanacak refahın sadece Güney Kıbrıs'ı kapsamasını ise ekonomik tehdit olarak görmüş, hem Türkiye'nin hem de Kuzey Kıbrıs'ın çıkarlarını korumak için gerekli adımları atmıştır. Diğer bir sorun ise bulunan kaynakların çıkarılması, kullanılması ve pazarlara iletilmesi konusunda ilişkilerin bozuk olduğu İsrail ile GKRY'nin aralarında yaptığı iş birliği olmuştur. Bu bölgesel iş birliğine yine ilişkilerin bozuk olduğu Mısır'ın da katılımı ile Türkiye'nin konuyu güvenlik bakımından da değerlendirmesine neden olmuştur. ${ }^{36}$ Bölgedeki çözüm arayışı içinde olan

Enstitüsü Raporu, Yakın Doğu Enstitüsü Yayınları, Lefkoşa/KKTC, 2019, Rapor No: 2/2019, 1-47, s. 44, http://yde.neu.edu.tr/wp-content/uploads/sites/142/2019/09/YDE_ Do\%C4\%9FuAkdenizEnerji-17.09.2019.pdf(Erişim Tarihi: 10.07.2020).

${ }^{35}$ Volkan Özdemir ve Hasan Barış "Uluslararası Ekonomi Politik Bir Değerlendirme Karadeniz ve Doğu Akdeniz Deniz Alanları Sorunu”, Turkish Studies Economics, Finance and Politics, Yaz 2018, 13(22), 401-416, s. 410-413.

${ }^{36}$ Abdullah Muhsin Yıldız, "Türkiye'nin Doğu Akdeniz'i Güvenlikleştirmesi”, Barış Araştırmaları ve Çatışma Çözümleri Dergisi, 2015, 3(1), 1-25, s. 1. 
696

Güvenlik

Stratejileri

Cilt: 16

Sayı: 35

devletler Türkiye ve KKTC'ni buradaki hakları bakımından haklı ya da haksız görseler bile, Türkiye GKRY'nin bölgedeki doğal kaynakların kullanımını tek taraflı olarak oldubittiye getirmesine müsaade etmemelidir. $^{37}$ Bununla beraber, Türkiye'nin bölgedeki sorunları aşabilmesi için özellikle bölgedeki iyi ilişki içinde olduğu kıyı devletleriyle siyasal ve ekonomik ilişkilerini artırmal, kötü olanlarıyla ise ilişkilerini iyileştirme yönünde çaba sarf ederek gerek güvenliğini garanti altına almalı, böylece ekonomik refahtan payını almanın yolunu aramalidir.

Şekil: 4 Türkiye ile Libya Arasında Akdeniz'de Belirlenen Deniz Yetki Alanlari ${ }^{38}$

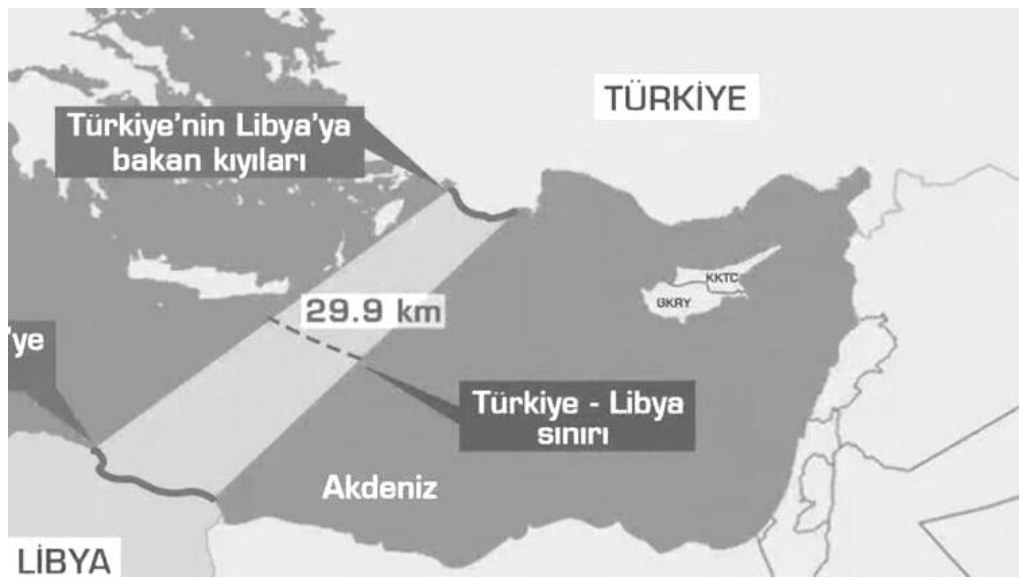

${ }^{37}$ Ulvi Keser ve Gökhan Ak, "Kıbrıs Adası Çevresindeki Deniz Dibi Hidrokarbon Zenginliklerinin Adadaki Sorunun Çözümüne Muhtemel Etkileri", Naciye Doratl1, (ed.), 8. Uluslararası Kıbrıs Araştırmaları Kongresi Bildirileri (25-27 Nisan 2012), Doğu Akdeniz Yayınları, 2013, C. 1, 143-161, s. 151, http://i-rep.emu.edu.tr:8080/ xmlui/handle/11129/4133 (Erişim Tarihi: 09.07.2020).

${ }^{38}$ Yorgo Kırbaki ve Uğur Ergan, “Türkiye'den Doğu Akdeniz'de Şah Mat”, HÜRRIYET Gazetesi, 02.12.2019, https://www.hurriyet.com.tr/dunya/turkiyeden-sah-mat-41387100 (Erişim Tarihi: 07.02.2020). 
Doğu Akdeniz'de artan gerilim askerî tatbikatların yapılmasında da artışlara neden olmuştur. Bölgede müttefik olan ülkeler ortak tatbikatlar düzenleyerek askerî kabiliyetlerini geliştirmeye çalışmaktadır. Türkiye tek taraflı ilan edilen MEB'lere karşı kendi MEB'sini belirlemiş ve 10 Nisan 2019 tarihinde Birleşmiş Milletler Genel Sekreterliğine vermiştir. Türkiye, olas1 gelişmelere karş1 gerek askerî seçeneği gerekse uzlaşma yollarının tamamını değerlendirmiş ve gerekli adımları atmıştır. ${ }^{39} \mathrm{Bu}$ çerçevede, Türkiye ve Libya Ulusal Mutabakat Hükümeti arasında her iki ülke için uluslararası hukukun imkân tanıdığı hakların korunmasını amaçlayan "Deniz Yetki Alanlarının Sınırlandırılmasına İlişkin Mutabakat Muhtırası" ve "Güvenlik ve Askerî İşbirliği Mutabakat Muhtırası" 27 Kasım 2019 tarihinde imzalandı. Bu muhtıraya göre Türkiye ile Libya arasında Akdeniz'de belirlenen deniz yetki alanları Şekil 4'de görülmektedir.

\section{Şekil: 5 Türkiye'nin Doğu Akdeniz'deki} Kita Sahanlığı ve MEB'si ${ }^{40}$

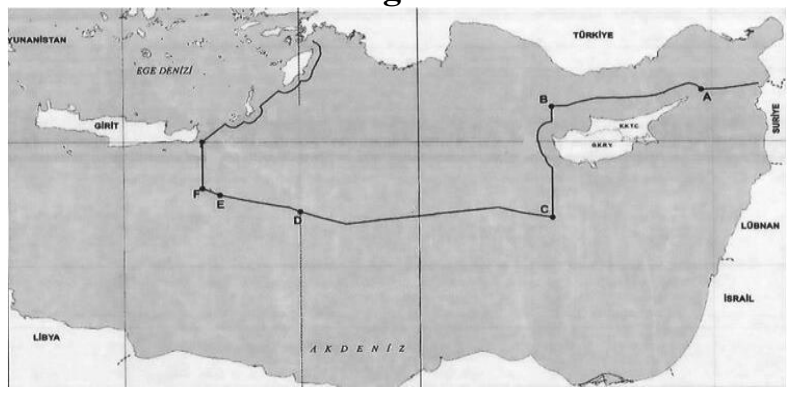

\footnotetext{
${ }^{39}$ Nejat Tarakçı, “Güç Dengeleri Işığında Türkiye'nin Doğu Akdeniz Stratejisi Nasıl Olmalıdır”, Türk Asya Stratejik Araştırmalar Merkezi (TASAM), İzmir, 2009, https://tasam.org/tr-TR/Icerik/51392/guc_dengeleri_isiginda_turkiyenin_dogu_akdeniz_ stratejisi nasil olmalidir (Erișim Tarihi: 28.06.2020).

${ }^{40}$ HÜRRIYYT Gazetesi, "Son Dakika: Yunanistan'ı Şoke Eden Tarihi Hamle Sonrası Türkiye O Haritayı Paylaştı!", (02.12.2019), https://www.hurriyet.com.tr/gundem/sondakika-disisleri-bakanligi-paylasti-iste-turkiyenin-dogu-akdenizdeki-kita-sahanligi-vemeb-sinirlari-41387569 (Erişim tarihi: 07.02.2020).
}

\section{7}

Güvenlik Stratejileri

Cilt: 16

Say1: 35 
698

Güvenlik Stratejileri

Cilt: 16

Sayı: 35
Türkiye'nin Libya ile imzaladığı "Deniz Yetki Alanlarının Sınırlandırılmasına İlişkin Mutabakat Muhtırası"nın ardından Türkiye'nin Doğu Akdeniz'deki kıta sahanlığını ve MEB sınırlarını gösterir harita Şekil 5'de görülmektedir. Buna göre A ve B noktaları arası 2011'de Türkiye ile KKTC arasında yapılan anlaşmada belirlenen hat, C, D ve E noktaları ise Türkiye ve Misır arasındaki "ana karalar arası ortay hattı" olarak işaretlenmiştir. E ve F olarak gösterilen noktalar da Türkiye ile Libya arasında imzalanan "Deniz Yetki Alanlarının Sinırlandırılmasına İlişkin Mutabakat Muhtırası" ile belirlenen hattır. ${ }^{41}$ Birleşmiş Milletler Deniz Hukuku Sözleşmesi'nin ilgili maddeleri de dâhil olmak üzere uluslararası hukuka uygun olarak imzalanan mutabakat muhtırası dünyada büyük yankı uyandırarak şaşkınlık yaratmıştır. Libya ile yapılan bu önemli iş birliği, Türkiye'nin Doğu Akdeniz'deki potansiyel enerji kaynaklarından alacağı payını artıracak ve küresel enerji arenasındaki elini güçlendirecektir.

\section{Sonuç}

Doğu Akdeniz ve Kıbrıs, tarih boyunca jeopolitik, jeostratejik ve jeoekonomik önemini korumuştur. Son dönemlerde bölgede zengin doğal gaz enerji kaynaklarının bulunması ve bunun sağlayacağı ekonomik faydanın paylaşılması konusu, çeşitli siyasi, ekonomik ve jeopolitik dengeler üzerinde duran bölgenin önemini daha da arttırmış ve oldukça zorlu politik güç mücadelelerine neden olmuştur. Bölgede denklemin sadece bir parametre üzerinden değil güvenlik, ekonomi, ticaret, dış politika gibi birçok parametreden meydana gelmesi, bölgenin hâlihazırda hassas bir zeminde oturmas1 ve yeni bulunan enerji kaynakları gibi nedenlerle durum daha da girift bir hal almıştır. Doğu Akdeniz'de bulunan kaynakların nasıl ve ne yönde değerlendirileceğine dair karar, bölge devletlerince sadece ekonomik fayda kriteri ile belirlenmemektedir. Güvenlik, dış politika, ticaret gibi birçok parametre etkili olmaktadır. Bu noktada alınan kararlar ekonomik fayda temelinden çok ülkelerin dış politik çıkarları doğrultusunda belirlenmektedir.

${ }^{41}$ HÜRRIYYT Gazetesi, “Son...”, (02.12.2019), a.g.y. 
Bu durum, bölgede politik bir ekonominin oluştuğunun göstergesi olmuştur.

Doğu Akdeniz'de önemli bölgesel güçlerden biri olan Türkiye ile MEB konusunda uzlaşılmadan Güney Kıbrıs'ın tek taraflı MEB ilan etmesi, henüz çözüme kavuşmayan Kıbrıs adasının ihtilaflı durumu da göz önüne alındığında, içinde bulunulan durum daha da karmaşıklaşmaktadır. Henüz münhasır ekonomik bölgelere dayalı rezerv çıkartılması ile ilgili uzlaşı sağlanmadan Güney Kıbrıs'ın kendi başına ilan ettiği parsellerde arama ve işletme ruhsatını vermesi siyasi krize sebep olmaktadır. Güney Kıbrıs'ın ruhsat için başta Fransa ve İtalya gibi devletler ile anlaşması bu ülkeleri de denklemin bir parçası haline getirmektedir. Kıbrıs adasındaki var olan ihtilaflı durumun üstüne bir de enerji rezervlerinin paylaşılması sorununun eklenmesi ve dahası bölge devleti olmayan ülkelerin de duruma müdahil olması, bölgede siyasi krizi derinleştirerek çözümsüzlüğe doğru itmektedir.

Türkiye, haklarını korumak ve Kıbrıs adası sorununun çözümü için bölgede başlattığı doğal gaz arama faaliyetlerini kararlı bir şekilde sürdürmelidir. Bu çabaların sonucunda doğal gaz rezervlerine ulaşılması GKRY'ni çözüm için müzakere masasına oturmaya zorlayacak, ayrıca bölgede söz sahibi olmak isteyen diğer ülkelere karşı elini güçlendirecektir.

Bölgenin durumu güvenlik boyutları bakımından incelendiğinde, devletlerin reel çıkarlarına göre karar verdiği açıkça görülmektedir. Ayrıca yapılan anlaşmaların sadece ekonomik yönde olmayıp, güvenlik boyutlarının da etkili olduğu anlaşılmaktadır. Sağlanan işbirlikleriyle Türkiye dışlanmaya çalışılmış, hatta dışlanmış ve bu nedenle Türkiye kendi MEB'sini ilan etmek durumda kalmıştır. Bu durumun iyice derinleşmemesi için, Lozan anlaşmasıyla uluslararası alanda egemenliği kabul edilen Türkiye Cumhuriyeti'nin uluslararası hukuktan doğan haklarından hareketle diğer devletlerle eşit kabul edilerek, uluslararası hukukun 1şı̆̆ında uzlaşı sağlanarak ortak çözümlerin bulunması gerekmektedir. Çözüm ise, bölgedeki hak sahibi taraflar arasında uluslararası hukuk kurallarına uygun olarak bir anlaşmanın yapılması ve dolayısıyla BMDHS'de belirtildiği gibi adil bir paylaşımın sağlanmasidır.

Güvenlik Stratejileri

Cilt: 16

Say1: 35 
700

Güvenlik Stratejileri

Cilt: 16

Sayı: 35

Uzlaşı zemininde bir çözüm için Türkiye, uluslararası hukuktan doğan haklarını uluslararası platformlarda uluslararası hukukun öngördüğü şekilde dile getirmeli ve açıklamış olduğu ekonomik münhasır bölgenin hangi kriterlere göre belirlediğini açıkça ortaya koymalıdır. Bölgede alınan kararların sadece ekonomik gerekçelerle alınmadığı gerçeğinden hareketle, Türkiye İsrail'in güvenlik kaygılarını, İsrail ise Türkiye'nin Filistin bölgesi üzerine insani kaygılarını dikkate almalı ve iki ülke karşılıklı çıkar temelinde güvenlik noktasında uzlaşı sağlamalıdır. Türkiye'nin açıkladığı MEB planına göre rezervlerin paylaşılması noktasında bölgedeki hak sahibi devletler ile en önemli muhatabı olan Mısır ve Libya örneğinde olduğu gibi tekrar diyaloğa geçilerek ikili ilişkilerle Güney Kıbrıs'ın dolaylı etkisini ortadan kaldırmalıdır. Doğu Akdeniz'de çıkarılan kaynakların Avrupa'ya iletilmesi noktasında Türkiye, gerekli girişimlerde bulunarak jeopolitik konumundan kaynaklı enerji merkezi olma seçeneğini değerlendirmeli ve bu doğrultuda gerekli altyapı çalışmalarını yapmalıdır. Doğu Akdeniz'de siyasi krizi daha da derinleştiren Kıbrıs meselesinde adanın tamamına nihai bir çözüm getirmek için GKRY'nin garantör ülkeleri olan İngiltere ve Yunanistan ile gerekli görüşmelerin zemini hazırlanmalıdır. Tüm bu süreçlerde Türkiye her türlü kuvvet çarpanını kullanılması seçeneğinin yanı sıra, uzlaşı için diyaloğa açık olduğunu belirtmelidir. Türkiye'nin atabileceği bu adımların paralelinde, bölge devletlerinin de karşılıklı çıkarlarının tatmin edildiği kalıcı olabilecek bir çözüm için tek taraflı ilandan kaçınmaları, dolayısıyla uzlaşı zeminde buluşmaları gerekmektedir. Ancak bu konular gerçekleştirilebildiği takdirde bölgenin ekonomik potansiyelinden tüm ülkeler adil bir şekilde ve azami olarak faydalanabilecektir.

\section{Summary}

Eastern Mediterranean has had geopolitic, geoeconomic and geostrategic significance in every period. It has never lost its position as the central region in matters such as transportation and trade. Lately, the significant amounts of hydrocarbon reserves in the region have increased its potential to be an energy centre and there are no exclusive economic zones determined by agreement between countries; these phenomena indicate that conflicts in this region will increase. 
In this region, which has global energy activity as a geographical location, Turkey is also a part of the conflict. In this respect, Turkey also aims to be a regional energy centre for sure. However, this also brings certain risks with it. From this perspective, this study aims to analyse the results of the recent developments in the region from geopolitical, geostrategic, geoeconomic and international security aspects and offer solutions to contribute to the literature.

The first part of the study focuses on the geoeconomic, geopolitical and geostrategic significance of the Eastern Mediterranean region and the Cyprus issue, while the second part discusses the size and economic values of natural gas reserves in the Eastern Mediterranean and evaluates the situation for Turkey. Afterwards, the political economy of natural gas reserves in the Eastern Mediterranean and the impact of international security dimensions are discussed, and proposals towards a solution are made.

A summary of the study is presented below:

The Eastern Mediterranean and Cyprus have historically maintained its geopolitical, geostrategic and geoeconomic significance. The fact that there are rich natural gas energy sources in the region and the matter of sharing the economic benefit it will provide have further increased the importance of the region which stands on various political, economic and geopolitical balances and has transformed it into various political power struggles. The fact that the equation in the region consists of not just one parameter but many parameters such as security, economy, trade and foreign policy causes the region to sit on a sensitive ground and the situation becomes even more intricate with new energy sources. The decision on how the resources in the region will be utilized are not determined only by the economic benefit criteria of the states in the region. Many parameters such as security, foreign policy, and trade are effective. At this point, the decisions taken are determined in the foreign political interests of countries rather than economic benefit. This has been an indication that a political economy is forming in the region.

The fact that Southern Cyprus has been declared a unilateral exclusive economic zone without reconciling on the exclusive economic 
702

Güvenlik Stratejileri

Cilt: 16

Sayı: 35

zone subject with Turkey, a major regional power in the Eastern Mediterranean, along with the conflictual status of the island of Cyprus which has not yet been solved have complicated the situation even more. The issue of Southern Cyprus licensing exploration and operation on the parcels it has declared to be its without consensus on the extraction of reserves based on exclusive economic zones has caused a political crisis. South Cyprus' agreement with states such as France and Italy for licensing makes these countries part of the equation. The addition of the non-sharing of energy reserves along with the existing conflictual island of Cyprus issue, and even the participation of countries that cannot become a regional state, deepen the political crisis in the region and push it towards insolvency.

In order to solve the Cyprus island problem, Turkey must continue its natural gas exploration activities in the region decisively. As a result of these efforts, accessing natural gas reserves will force Southern Cyprus to sit at the negotiation table for a solution, as well as strengthen its hand against other countries seeking a say in the region.

When the security aspects of the region are examined, states decide according to their real interests. It is understood that the agreements are not only in the economic, but also in the security aspect. The cooperation provided has left Turkey in an external position and Turkey had to declare its own exclusive economic zone. In order to resolve this situation before it deepened, the Republic of Turkey, the international sovereignty of which has been agreed upon with the Treaty of Lausanne, must be recognized as an equal to other states as a result of its rights arising from international law and has to find a solution in order to conclude an agreement in the light of international law. The solution is to share in a way that complies with international law and is fair as stated in UNCLOS, and to make an agreement between parties.

For a solution on the basis of reconciliation, Turkey must express its rights arising from international law on international platforms as stipulated by international law and explain the criteria under which the economic exclusive region it has announced has been determined. Based on the fact that decisions in the region are not taken only on economic grounds, Turkey should consider Israel's security concerns and Israel 
should take into account Turkey's humanitarian concerns over the Palestinian region and the two countries must reach consensus on the basis of mutual interest. According to the exclusive economic zone plan announced by Turkey, the most important interlocutor in the sharing of reserves, as in the case of Egypt and Libya, should re-enter into dialogue and eliminate the indirect influence of Southern Cyprus with bilateral relations. At the point of transmission of these resources in the Eastern Mediterranean to Europe, Turkey should take the necessary initiatives to become an energy centre due to its geopolitical position, and the necessary infrastructure works should be carried out in this direction. For the Cyprus issue, which deepens the political crisis in the Eastern Mediterranean, the ground for the necessary negotiations with the UK and Greece, the guarantor countries, must be laid up to bring a final solution to the entire island. In addition to using all kinds of force multipliers in all these processes, Turkey should state that it is open to dialogue for reconciliation. In addition to these steps that Turkey can take, the states of the region must meet on the basis of reconciliation by avoiding unilateral declarations for a solution where mutual interests are satisfied which can only be permanent in this way. However, if this can be realized, all countries will be able to benefit fairly from the economic potential of the region.

\section{Kaynakça}

Kitaplar

AĞAOĞLU, Levent, Kıbrıs Dünyanın Merkezidir, Hiperlink Yayınları, İstanbul, 2018. KOCAMANOĞLU, Ali, Türkiye Açısından Doğu Akdeniz'in Stratejik Önemi, Deniz Basımevi, İstanbul, 2005.

PAZARCI, Hüseyin, Uluslararası Hukuk, Turhan Kitabevi, Ankara, 2008.

YAYCI, Cihat, Sorular ve Cevaplar ile Münhasır Ekonomik Bölge (MEB) Kavramı, Deniz Basımevi Müdürlüğü, İstanbul, 2019.

YILDIZ, Dursun, Akdeniz'in Doğusu (Tarihi Geçmişi, Stratejik Önemi ve Su Sorunu Açısından), Bizim Yayınlar Kitabevi, İstanbul, 2008.

YILDIZ, Dursun, Doğu Akdeniz'de Isinan Sular, Bizim Kitaplar Yayınları, İstanbul, 2009. 
Hüseyin Tamer HAVA

704

Güvenlik

Stratejileri

Cilt: 16

Sayı: 35

YILDIZ, Dursun ve Doğan YAŞAR, Doğu Akdeniz'de Küresel Satranç, Truva Yayınları, İstanbul, 2012.

\section{Kitap Bölümleri}

AKSU, Fuat, "Doğu Akdeniz Deniz Yetki Alanları Sorunu ve Türkiye-AB İlişkileri", Sertaç Hami Başeren (Yay. Haz.), Doğu Akdeniz'de Hukuk ve Siyaset, A.Ü. Siyasal Bilgiler Fakültesi Yayınları, Ankara, 2013, s. 159-196.

\section{Makaleler}

AK, Gökhan, "Kıbrıs Adası Çevresindeki Deniz Dibi Hidrokarbon Zenginliklerinin Adadaki Sorunun Çözümüne Muhtemel Etkileri", Motif Akademi Halkbilimi Dergisi, 2013, Say1 1 (Kıbris Özel Sayıs1-I), s.333-338, https://dergipark.org.tr/tr/pub/ mahder/issue/28390/301912 (Erişim Tarihi: 09.07.2020).

AKARÇAY, Pınar ve Gökhan AK, "Ulusal Güvenlik Bağlamında Kıbrıs: Jeostratejik/Jeoekonomik Önem ve Gelişmeler", Çeşm-i Cihan Tarih Kültür ve Sanat Araştırmaları E-Dergisi, Yaz 2018, 5(1), s.140-157, https://dergipark.org.tr/tr/pub/ cesmicihan/issue/38085/427535 (Erişim Tarihi: 09.07.2020).

AYDIN, Yusuf Alperen, “18. Yüzyılda Osmanlı Devleti'nin Ege (Adalar) Denizi ve Doğu Akdeniz'e Yönelik Güvenlik Parametreleri”, Osmanlı Araştırmaları / The Journal of Ottoman Studies, 2015, Say1 45, s. 161-184.

BAŞEREN, Sertaç Hami, "Doğu Akdeniz Deniz Yetki Alanları Uyuşmazlığı", Stratejik Araştırma ve Etüt Merkezi Stratejik Araştırmalar Dergisi, 2010, 8(14), s. 133-155.

DOĞRU, Sami, "Doğu Akdeniz'de Hidrokarbon Kaynakları ve Uluslararası Hukuka Göre Bölgedeki Kıta Sahanlığı ve Münhasır Ekonomik Bölge Alanlarının Sınırlandırılması", Türkiye Barolar Birliği Dergisi, S. 119, 2015, s. 503-554, https://hdl.handle.net/20.500.12507/96 (Erişim Tarihi: 08.07.2020).

ERBAŞ, Fatih, "19. Yüzyıl Doğu Akdeniz Donanma Mücadelesinde Öne Çıkan Devletler ve Faktörler”, FSM İlmî Araştırmalar İnsan ve Toplum Bilimleri Dergisi, 2016, Say1 8, s. 133-158.

ERTÜRK, Muzaffer, "Doğu Akdeniz'de Türk-Yunan Enerji Uyuşmazlığı”, Journal of Current Researches on Social Sciences, 2017, 7(2), s. 15-26.

KARAPINAR, Nuray, "Birleşmiş Milletler Deniz Hukuku Sözleşmesi ve Deniz Alanlarına İlişkin Bazı Kavramlar", MTA Doğal Kaynaklar ve Ekonomi Bülteni, 2015, Say1 20, s. 13-21, http://www.mta.gov.tr/v3.0/sayfalar/hizmetler/kutuphane/ekonomibultenleri/2015 20/3.pdf (Erişim Tarihi: 27.06.2020).

KEDIKLII, Umüt ve Deniz TAŞKIN, "Enerji Kaynakları Mücadelesinde Doğu Akdeniz Havzası ve Deniz Yetki Alanları", Alternatif Politika, Ekim 2015, 7(3), s. 399-424.

KESER, Ulvi ve Gökhan AK, "Kıbrıs Sorunu ve Deniz Hukuku Bağlamında Doğu Akdeniz'de Yapılması Gerekenler", Klbrıs Araştırmaları ve Incelemeleri Dergisi, Ocak 2018, 1(2), s. 95-107, https://dergipark.org.tr/tr/pub/kaid/issue/35246/391038 (Erişim Tarihi: 09.07.2020).

ÖZDEMIR, Volkan ve Hasan BARIŞ, "Uluslararası Ekonomi Politik Bir Değerlendirme Karadeniz ve Doğu Akdeniz Deniz Alanları Sorunu”, Turkish Studies Economics, Finance and Politics, Yaz 2018, 13(22), s. 401-416.

TAMÇELIK, Soyalp, “Jeopolitik Teoriler Açısından Kıbrıs'ın Önemi (The Importance 
Doğu Akdeniz'deki Doğal Gaz Rezervlerinin

Ekonomik ve Güvenlik Boyutuyla Türkiye Açısından Değerlendirmesi

Of Cyprus Island in Geopolitical Theories)", Center for Turkish Studies Occasional Paper Series-Book 3, 2011, s. 1-32, http://pdxscholar.library.pdx.edu/turkish studies_occasionalpaper/3 (Erişim Tarihi: 09.07.2020).

TAŞCIOĞLU, Ömer Lütfi, “GKRY'nin Türkiye Cumhuriyeti'ne ve Kuzey Kıbrıs Türk Cumhuriyeti'ne Ait Deniz Yetki Alanlarındaki Petrol ve Doğal Gaz Arama Çalışmaları ve Münhasır Ekonomik Bölge Anlaşmaları", Social Sciences Studies Journal, 2018, 4(26), s. 5697-5709.

YAYCI, Cihat, "Doğu Akdeniz'de Deniz Yetki Alanlarının Paylaşılması Sorunu ve Türkiye", Bilge Strateji, 2012, 4(6), s. 1-70, https://dergipark.org.tr/en/pub/bs/issue/ 3804/51021 (Erişim Tarihi: 25.12.2019).

YILDIZ, Abdullah Muhsin, "Türkiye'nin Doğu Akdeniz'i Güvenlikleştirmesi”, Barış Araştırmaları ve Çatışma Çözümleri Dergisi, 2015, 3(1), s. 1-25.

\section{Raporlar}

ECE, Jale Nur, "Kabotaj, Münhasır Ekonomik Bölge, Petrol ve Doğal Gaz Haklarımız", ORSAM (Ortadoğu Stratejik Araştırmalar Merkezi) Raporu, Temmuz 2013, Rapor No: 33, s. 1-19.

KARAGÖL, Erdal Tanas ve Büşra Zeynep ÖZDEMİ, “Türkiye'nin Enerji Ticaret Merkezi Olmasında Doğu Akdeniz'in Rolü’, SETA Raporu, 2017, Yayın No: 92, s. 1-63. ŞAFAK, Erdi, "Doğu Akdeniz'de Enerji Bağlamında Değişen Dengeler", Yakın Doğu Enstitüsü Raporu, Yakın Doğu Enstitüsü Yayınları, Lefkoşa/KKTC, 2019, Rapor No: 2/2019, s. 1-47, http://yde.neu.edu.tr/wp-content/uploads/sites/142/2019/09/YDE_ Do\%C4\%9FuAkdenizEnerji-17.09.2019.pdf (Erişim Tarihi: 10.07.2020).

\section{Bildiriler}

KESER, Ulvi ve Gökhan AK, "Kıbrıs Adası Çevresindeki Deniz Dibi Hidrokarbon Zenginliklerinin Adadaki Sorunun Çözümüne Muhtemel Etkileri”, Naciye Doratl1, (ed.), 8. Uluslararası Kıbrıs Araştırmaları Kongresi Bildirileri-(25-27 Nisan 2012), Doğu Akdeniz Yayınları, 2013, C. 1, s. 143-161, http://i-rep.emu.edu.tr:8080 /xmlui/handle/11129/4133 (Erişim Tarihi: 09.07.2020).

TAMÇELIK, Soyalp, "Kıbrıs'ın Batı Dünyası Açısından Jeopolitik Önemi ve Siyasî Algılamaları", 2. Uluslararası Kıbrıs Sempozyumu Bildiriler Kitabı-(21-25 Ekim 2010 İmir), Ulvi Keser, (Kıbrıs Türk Kültür Derneği Adına Yay. Haz.), Motif Matbaacılık, Ankara, 2011, C. 3, s. 225- 282, https://websitem.gazi.edu.tr/site/soyalp/files (Erişim Tarihi: 13.07.2020).

TAMÇELIK, Soyalp ve Emre KURT, “Türkiye'nin Münhasır Ekonomik Bölge Algısı ve Yakın Tehdit Alanı: Kıbrı”, Uluslararası Güvenlik Kongresi Bildiriler Kongresi Bildirileri Kitabı, Hasret Çomak ve Ayşegül Gökalp Kutlu, (ed.), Kocaeli Üniversitesi Yayınları, Kocaeli, Nisan 2014, C. 3, s. 882-913, https://www.researchgate.net/publication/ 312057624_Turkiye'nin_Munhasir_Ekonomik_Bolge_Algisi_ve_Yakin_Tehdit_Alani_Kib ris (Erișim Tarihi: 13.07.2020).

\section{Internet Kaynaklart}

CAN, Faruk, "Doğu Akdeniz: Ne Kadar Doğal Gaz Rezervi Var, En Büyük Payı Hangi Ülkeler Alacak?", EURONEWS, 05.05.2019, https://tr.euronews.com/2019/05/05/doguakdeniz-ne-kadar-dogal-gaz-rezervi-var-en-buyuk-payi-hangi-ulkeler-alacak (Erişim Tarihi: 
Hüseyin Tamer HAVA

706

Güvenlik

Stratejileri

Cilt: 16

Sayı: 35

25.12.2019).

DİLEK, Bahadır Selim, "Akdeniz'de Sanal Petrol Oyunu", http://www.emo.org.tr/ ekler/c03b704b8bd986e_ek.pdf?dergi=508 (Erişim Tarihi: 30.05.2019).

ERCÜMEN, Merve Aksoy, "Doğu Akdeniz Enerji Rekabeti", İnsani ve Sosyal Araştırmalar Merkezi (INSAMER), 09 Eylül 2016, https://insamer.com/tr/doguakdeniz-enerji-rekabeti_366.html (Erişim Tarihi: 25.12.2019).

HÜRRIYET Gazetesi, “Son Dakika: Yunanistan'ı Şoke Eden Tarihi Hamle Sonrası Türkiye O Haritayı Paylaştt!", (02.12.2019), https://www.hurriyet.com.tr/gundem/sondakika-disisleri-bakanligi-paylasti-iste-turkiyenin-dogu-akdenizdeki-kita-sahanligi-vemeb-sinirlari-41387569 (Erişim Tarihi: 07.02.2020).

KARAHASAN, Sefa, “Türkiye'ye Karşı 3'lü Hamle! İmzalar Atıldı”, HÜRRIYET Gazetesi, 02.01.2020, http://www.hurriyet.com.tr/gundem/son-dakika-haberiturkiyeye-karsi-3lu-hamle-imzalar-atildi-41411242 (Erişim Tarihi: 03.01.2020).

KIRBAKİ, Yorgo ve Uğur ERGAN, "Türkiye'den Doğu Akdeniz'de Şah Mat", HÜRRIYET Gazetesi, 02.12.2019, https://www.hurriyet.com.tr/dunya/turkiyeden-sahmat-41387100 (Erişim Tarihi: 07.02.2020).

PAMİR, Necdet, "Enerji Politikaları ve Küresel Gelişmeler”, s. 57-73, https://docplayer.biz.tr/31939987-Enerji-politikalari-ve-kuresel-gelismeler.html (Erişim Tarihi: 13.07.2020).

ROBERTSON, Jessica, "Natural Gas Potential Assessed in Eastern Mediterranean", USGS Newsroom, 04.08.2010, https://archive.usgs.gov/archive/sites/www.usgs.gov/ newsroom/article.asp-ID=2435.html (Erişim Tarihi: 30.05 .2019 ).

TARAKÇI, Nejat, "Güç Dengeleri Işığında Türkiye'nin Doğu Akdeniz Stratejisi Nasıl Olmalıdır”, Türk Asya Stratejik Araştırmalar Merkezi (TASAM), İzmir, 2009, https://tasam.org/tr-TR/Icerik/51392/guc_dengeleri_isiginda_turkiyenin_dogu_akdeniz_ stratejisi_nasil_olmalidir (Erişim Tarihi: 28.06.2020)

TIRYAKIOĞLU, Muhsin Barış, "Doğu Akdeniz'de Enerji Denklemi-1”, Anadolu Ajansl, 09.05.2019, https://www.aa.com.tr/tr/analiz/dogu-akdenizde-enerji-denklemi1/1474137 (Erişim Tarihi: 12.04.2020).

USGS, "Undiscovered Oil and Gas of the Nile Delta Basin, Eastern Mediterranean", USGS Fact Sheet 2010-3027, May 2010, https://pubs.usgs.gov/fs/2010/3027/pdf/FS103027.pdf (Erişim Tarihi: 30.05.2019). 